\title{
Ssciendo
}

Ethics \& Bioethics (in Central Europe), 2019, 9 (3-4), 197-207

DOI:10.2478/ebce-2019-0021

\section{Wolf Hall and moral personhood}

\author{
Nora Hämäläinen ${ }^{1}$
}

\begin{abstract}
Can a good man do evil things? This paper offers a moral philosophical reading of Hilary Mantel's novels Wolf Hall and Bring up the bodies, focusing on Mantel's fictional portrayal of Thomas Cromwell as a good person, in spite of his growing involvement in the dirty work of Henry VIII. The narrative resists interpretations of Cromwell as someone corrupted by power. It also thwarts attempts to read his deeds as results of a deficient capacity for sympathetic imagination, which has been a focalized moral flaw in contemporary moral philosophical discussions of literature. By thus resisting moralized readings of his character, the novels invite intensified attention to the complex dynamics of character and circumstance.
\end{abstract}

Keywords: ethics, philosophy and literature, character, Hilary Mantel, Wolf Hall, Bring up the Bodies

This paper is an exercise in what has been called "reading for character" in a double sense; that is, reading a fictional text with special emphasis on both fictional characters and questions of moral character. This mode of reading has in the past few decades served the needs of philosophers who are interested in moral personhood, virtues, and the situation-bound features of moral action. Literary scholars have tended to find this mode of reading naïve, among other things because it may run the risk of isolating characters from the text of which they are parts and to disregard a more thorough analysis of the formal and aesthetic features of the literary work. $^{2}$

I will not dispute this assessment or worry here: as a type of reading, reading for character is narrow and partial. Nevertheless, it has its distinctive forms of usefulness that are currently increasingly appreciated by literary scholars as well, following the critical interventions of Rita Felski (2008, 2015) and Toril Moi (2017) for example. For the non-academic reader, thinking about literary characters often offers a first path of reflective engagement with the world of the literary work. We engage with characters, get to know them, admire them, sympathize with them and judge them. In this sense reading stories is a moral endeavor in a very broad sense. For the philosopher, the practice of reading for character can have a variety of uses. I will here put it to work to illuminate certain aspects of the relationship between moral personhood and situatedness and its implications for moral philosophy more generally.

Philosophers, when approaching literature for insight into moral personhood, have often in the past decades found special interest in characters that are particularly admirable or are developing in a moral respect. This is the central form of thinking about moral personhood in Martha Nussbaum's now classic essays on Henry James's late novels, where the great and developing sensibility and perceptiveness of the central characters make them ideal companions of what Nussbaum presents as an Aristotelian outlook on morality (Nussbaum, 1990). As a corollary to this approach some philosophers have discussed evil characters in literature and film, and the problems relating to how we identify or sympathize with obviously evil characters (Kieran, 2003).

Yet a perhaps more interesting and potentially jarring category of literary characters - both from the point of view of philosophy and from the point of view of aesthetics - are those that

\footnotetext{
1 University of Pardubice, Centre for ethics as study in human value, Pardubice (Czech Republic); nora.hamalainen@upce.cz

${ }^{2}$ For a philosophical critique of this kind of reading, see Vogler (2007).
} 
exhibit a mixture of unusual goodness and unusual evil in action or character. ${ }^{3}$ What makes such characters interesting is precisely how they resist readings, not only in the register of ethical criticism proposed by Nussbaum, but also in other familiar ways of deriving "the moral of the story". Yet these kinds of narratives are not external to moral thought. It would perhaps be easy to interpret such narratives as amoralist, disregarding or sidestepping moral thought in favor of aesthetic goals, entertainment or accuracy of depiction. But this is too simple. On the contrary, some such stories can rather be seen as intensely engaged with questions concerning the nature of good and evil and the complexities of moral personhood. My focal case here is a novel of this kind.

I'm concerned with the relationship between personal excellence (skill, capacity, intelligence, charm, perceptiveness, humanity) on the one hand and moral personhood on the other hand, as they appear in the guise of the fictionalized Thomas Cromwell in Hilary Mantel's novels Wolf Hall (2009) and Bring up the bodies (2012). The third and final novel in the series, with the prospective title The mirror and the light has not yet appeared at the time of writing this paper.

Mantel has in the novels chosen to narrate one of the bloodiest epochs of English history through the character of Thomas Cromwell, the blacksmith's son from Putney, who in the early $16^{\text {th }}$ century, a time of practically no social mobility between the lower and the highest echelons of society, becomes the most influential man in the realm. This is of course also a period that has fascinated historians and artists for centuries, and has been written about from many different perspectives. I will not here take a stand on how Mantel's work should be placed in this context of historical interpretations, but merely discuss an aspect of its moral philosophical interest as a literary work.

I argue that the ethical import of Mantel's Cromwell novels lies precisely in how they seamlessly mix evil and admirability in one character, challenging us to rethink certain aspects of what we think we know about moral personhood. I am not so much interested in what kinds of moral attitudes or skills we may learn or unlearn from Cromwell, but rather in what Cromwell's complex character and the complexities of our sympathy may teach us about the nature of lived morality.

It should perhaps be emphasized that I will not here go into the question of historical accuracy in depiction, that is, questions of what Cromwell was really like, or how we should understand the historical Cromwell's actions, or whether we should side with Cromwell or some other historical figure, such as Thomas More, in the central political conflicts of the day. What we have is a fictional character, constructed to do certain things to us and for us in our own present.

\section{The outline of Wolf Hall}

'So now get up.' Felled, dazed, silent, he has fallen; knocked full length on the cobbles of the yard. His head turns sideways; his eyes are turned towards the gate, as if someone might arrive to help him out. One blow, properly placed, could kill him now. Blood from the gash on his head - which was his father's first effort - is trickling across his face. Add to this, his left eye is blinded; but if he squints sideways, with his right eye he can see that the stitching of his fathers' boot is unraveling. The twine has sprung clear of the leather, and a hard knot in it has caught his eyebrow and opened another cut (Mantel, 2009, p. 3).

This story of Cromwell begins with a boy severely, dangerously beaten by his father because of a fight where the boy has knifed another boy. After a night of recovery in his married sister's

\footnotetext{
${ }^{3}$ For an interesting discussion of a similar issue in relation to Dimitri Karamazov, see Pacovská (2019).
} 
household, young Cromwell flees from the possible legal consequences of his deed, and the anger of his father, to Europe.

The book takes its title - Wolf Hall - from the estate of the Seymour family, which will have a central role in the follow-up novel, Bring up the bodies. In the first novel the title offers a premonition of what is to come, but also an image of the relations between the human beings depicted in the novel, where treachery, cruelty and violence are predominant.

The novels are written in a realistic style, with care for historical detail, and consistently focalized through Cromwell himself. In spite of the realism they read as a kind of super hero fiction, highlighting Cromwell's superior capacities of thought and action, but also his loyalty, resilience, and capacity for love and pity. Indeed, the excellences of Cromwell can be read as part of the realism. We are invited to ask: how else, than by massive innate talent, could a person of such lowly birth have climbed so high?

Of Cromwell's youth and European adventures, we learn only glimpses and reminiscences. When he returns to England, he is no longer the young curious brute that we encountered at the beginning. Learned in trade and law, proficient in many languages, he marries a young widow and gains with her a small wool trade business which he rapidly expands.

Capable and useful in many ways he enters the service of cardinal Wolsey, who is one of the most powerful men in England at the time. This is how Cromwell, in his late thirties or early forties, is described:

\begin{abstract}
It is said that he knows by heart the entire New Testament in Latin, and so as a servant of the cardinal is apt - ready with a text if abbots flounder. His speech is low and rapid, his manner assured; he is at home in courtroom or waterfront, bishop's palace or inn yard. He can draft a contract, train a falcon, draw a map, stop a street fight, furnish a house and fix a jury. He will quote a nice point in the old authors, from Plato to Plautus and back again. He knows new poetry, and can say it in Italian. He works all hours, first up and last to bed. He makes money and spends it. He will take a bet on anything (Mantel, 2009, p. 31).
\end{abstract}

Wolsey takes a liking to him, both for his intelligence and for the fact that he, like Wolsey himself, is of lowly birth. He soon becomes indispensable for the cardinal.

Meanwhile the king, Henry VIII, is concerned by the absence of an heir. Only one of his many children with Catherine of Aragon, the adolescent princess Mary, has survived infancy. The king now wants to seek annulment of his marriage from the pope, in order to be able to remarry and conceive a legitimate son. In Catherine's place he wants to marry the ambitious though insignificant young noblewoman, Anne Boleyn, for whom he has developed an allconsuming passion. Cardinal Wolsey fails to negotiate the annulment with the pope and falls into disgrace with the king. Henry breaks his relations with the pope. The cardinal is chased away from his lodgings at Westminster and deprived of his belongings, and dies in seclusion, avoiding the foreshadowing arrest and execution. The king declares himself head of the church in England, installs Thomas Cranmer as the reforming Archbishop of Canterbury, gets his marriage annulled, marries Anne Boleyn and crowns her queen. Anne gives birth to a child who turns out to be a girl.

Cromwell's role in all of this is full of ambivalences, he is loyal to Wolsey but sympathetic of the ideas of the reformation, reading the bible in English and corresponding with its clandestine translator William Tyndale, who is hiding abroad. He keeps visiting Wolsey in his exile, but also turns to offer his services to the king, thus opening for a transfer of his loyalties to Henry at Wolsey's death, helping him with the legal and strategic details of marrying Anne Boleyn. Well versed in the literature and diplomacy of his time (Machiavelli's The Prince, Castiglione's The book of the courtier), he is reflective about the nature and basis of his task, 
noting that "you have to choose your monarch". And soon indeed, he becomes the king's "right hand".

After Wolsey's death Cromwell gives himself two tasks which stand in profound conflict: to serve the monarch in every way he can (a task which in the end cannot fail to compromise him) and yet to revenge on the cardinal's behalf (a task which at least in modern terms is morally compromised from the start).

His relation to Anne Boleyn is complex: he sees her at first as a kindred spirit, a person of voracious ambition and an iron will. He helps her to become queen, but when she falls out of grace with the king, he also helps him to get rid of her. At the end of Bring up the bodies she is executed for treason in the form of supposed sexual relations with five men: her own brother George Boleyn, the king's attendants Henry Norris, Francis Weston and William Brereton, and the court musician Mark Smeaton, who have been executed some days before. In Mantel's story the conviction and executions of these men is the culmination of Cromwell's personal revenge: they personify for him the crimes committed against Cardinal Wolsey. The king remains immune to his reproach, but these men are privately convicted by Cromwell, among other things for laughingly taking part in a court play which mocked the cardinal after his death. Thus, as Cromwell notes: "He needs guilty men. So he has found guilty men. Though perhaps not guilty as charged" (Mantel, 2009, p. 392).

We may add to this, among other things, Cromwell's services in the reorganization of monastic orders that contribute substantially to his own as well as the king's funds, while putting monks and nuns out on the street. He is a man guided by a hunger for power, personal wealth and revenge. These are all essential parts of the story. And yet, as Mantel has portrayed him, Cromwell remains, at least to the end of the second book, in all essentials, a good person.

\section{A good person?}

Mantel's Cromwell makes an immediate claim on the readers love and loyalty, and keeps them in his possession until the end of the second book. He also has many moral virtues to add to his practical and intellectual excellence.

First, he is an industrious family man, much loved and trusted by his family, his wards and his servants. He is also constantly at work with some business or other, first in the wool trade, then for the cardinal and last for the king. These features make his existence a model of what Charles Taylor (1989) called the "affirmation of ordinary life", the idealization of the life of production and reproduction emblematic of modernity. In this respect he is perhaps too modern for his time. The defining themes of his private life are the loss of his wife and two young daughters, the loving care for his wards and the love for his son Gregory, the only remaining child, who is growing into a gentleman very different from his father.

Second, he is also presented as a loyal friend. A central part of his capacity to act is premised on his network of business friends throughout Europe. He does his best to help friends who are locked up in the tower of London as heretics. His relationship to Cardinal Wolsey is that of a loving son and faithful apprentice.

Third, he has moral curiosity and something we may call an active social conscience:

Daily he ponders the mystery of his countrymen. He has seen killers, yes; but he has seen a hungry soldier give away a loaf to a woman, a woman who is nothing to him, and turn away with a shrug. It is better not to try people, not to force them to desperation. Make them prosper; out of superfluity, they will be generous. Full bellies breed gentle manners. The pinch of famine makes monsters (Mantel, 2012, p. 41).

Fourth, he is rational, sensible and pragmatic, in a way which helps him steer clear of moralism and ideological excess. He feels distaste for what he sees as the fanaticism of people like 
Thomas More, who tortures people while reading the gospel to them, or his protestant friends who sacrifice their lives through theological stubbornness.

$\mathrm{He}$ also has an unusually well-developed capacity for engaging with the perspective of others, for noticing people, assessing their characters and remembering them, regardless of their social position. And perhaps above all, the reader takes pleasure in seeing the world through his eyes, following the quickness of his thought and complex accuracy of his judgment.

Yet, these things said, the drama of the novels lies not in any display of Cromwell's moral excellence, but in two themes of moral corruption: unrelenting ambition (paralleled only by that of Anne Boleyn) and revenge. The ethically challenging dimension of the novel's construction is how Mantel manages to keep him good while letting him be ultimately moved by these forces.

A rough preliminary answer to how this is possible could be formulated like this: revenge is partly sanctified as an expression of his love of the Cardinal. It is the proof that he did not, in the end, fail his master. This does not make much sense in modern terms, but it does so within the emotional and evaluative landscape of the novel. The case of his ambition is quite different: within the novel's world, innate ambition is impious. It is a breach against the order of God by aiming too high. Or at least it can be talked about in this way. Yet by the standards of the reader's world, the modern one, the ambition of the talented is one of the highest virtues. We grant Cromwell the right to pursue a position by the king's side, because his ambition seems more a consequence than the motor of his capacity to achieve what he decides upon. But then, at some point, what was ambition turns into necessity and he cannot but serve the king: the claws of the lion enclose him gently but firmly.

Revenge out of love, on the one hand, and callousness out of necessity caused by ambition, on the other hand. Both his love and his ambition seem to save this character from the reader's harsh judgment. But this is only to be seen as a very rough and preliminary explanation to the reader's persistent sense that he is, in spite of all, a good person.

\section{Cromwell, Eichmann and Michael Corleone}

Philosophers writing on the ethical role of literature, including Martha Nussbaum, Cora Diamond (1991), Richard Rorty (1989), Iris Murdoch (1992, 1997), and Alice Crary (2016) have tended to focus the importance of the imagination for a person's moral character and have seen a lack of imagination as a central source of evil. Imaginative engagement with others, and the capacity to translate it to compassionate and morally responsive action, are the cornerstones of the normative ethical outlook, or ethical ideal, put forward by these philosophers. We do not need to claim that this is a particularly modern or late modern ethical view, but it is certainly a view that has special resonance in our time. This sensibility was shared by, among others, Hannah Arendt. In her book Eichmann in Jerusalem (2006) Arendt diagnoses Adolf Eichmann's brand of evil as premised on his lack of imagination. As an embodiment of modern bureaucracy, he takes pride in performing his duties within the Nazi machinery. His dutifulness goes hand in hand with the complete absence of a capacity for imaginative engagement with the people whose lives he is destroying. Even his language is simplified, full of platitudes and borrowed phrases that speak of an incapacity to think and imagine for himself. He has, in Arendt's story, no desire to do evil, no grudge against the people whose lives are in his hands, not even a developed anti-Semitist creed. He is just obeying orders, doing what he thinks is the right thing to do and hoping to distinguish himself in the eyes of his superiors. His emotional range is described as narrow and his ambitions petty.

Through his sensibility and imagination Cromwell serves as an antidote to this kind of bureaucratic evil, because Cromwell's capacity to think, feel and imagine are well developed. He is, like Eichmann, above all a servant of power and he obeys orders in a thoroughly hierarchical society. But he does so creatively, seeing, imagining and acting for the king. Once brought to his elevated position through talent and ambition, he is no longer able to withdraw. 
His life and his large household are wholly dependent on his capacity to serve. He is too useful to the King to be let go. He is, furthermore, not a person like the novels' fictionalized Thomas More, who would risk his own life or the lives of others for the sake of some principle. Up to the end of the second novel he sees exactly what he is doing, and why he is doing it. Without ever losing his imaginative capacities, or his full acknowledgement of what his actions mean to all concerned, he proceeds to make possible the executions, which are both his service to the king and his revenge on behalf of his former master. His ward Rafe Sadler asks him:

[C]ould the Kings freedom be obtained, sir, with more economy of means? Less bloodshed? Look, he says: once you have exhausted the process of negotiation and compromise, once you have fixed on the destruction of an enemy, that destruction must be swift and it must be perfect. Before you even glance in his direction, you should have his name on a warrant, the ports blocked, his wife and friends bought, his heir under your protection, his money in your strong room and his dog running to your whistle. Before he wakes in the morning, you should have the axe in your hand (Mantel, 2012, p. 417).

Concerning the roles of his talent and ambition in the narrative construct, Cromwell can usefully be compared to the character Michael Corleone as he is rendered in Coppola's movie, The Godfather. Michael is initially the clever college boy whose role in the family is to make the Corleone name respectable. But when his father is shot and wounded by rival mafia families and his older brother, Sonny, is killed, Michael, through well-planned revenge on his father's behalf, enters the position as head of the family.

But The Godfather, with its sequels, is a story about the moral corruption of an individual, Michael, through a series of violent deeds that place him firmly in a chain of generations of violence and crime, from which both he and his father thought he could escape. Michael Corleone, like Mantel's Cromwell, is a character of great innate talent and intelligence, and a capacity for imagination and love. They are both led on the path of destruction precisely by their superior intelligence. Michael shoulders the leading role in the family because he can, and he thinks he has to. Cromwell runs the king's dubious errands because he can and because he thinks he has to. Only through their remarkable ability to plan, foresee and manipulate, are they capable of what they do. They both follow a similar logic of situation, opportunity, talent and necessity: differently placed, the same capacities could have worked for the good. But the comparison brings out precisely what is particular to Mantel's story up to the end of the second book. Michael's relations to his loved ones are seriously damaged by his success as the new godfather -he sacrifices the family that he wanted to protect: he drives away his wife and orders the killing of his own brother. The young intelligent man is destroyed by the godfather he has become. This story is easy to understand in terms of conventional morality and psychology, and it fits well with a neo-Aristotelian idea of the unity of virtue. Against its recognizable moral logic, we are left to baffle at Cromwell, who at the height of his power, at the execution of Anne Boleyn, retains his clarity of mind and his purity of heart, although fear is tightening its grip on him.

Or perhaps this should be posed as a question: what has he gained or lost? A scene, shortly before his plot is finalized, delicately depicts his ambivalence. He looks at a tapestry that he has received as a gift form Cardinal Wolsey many years ago, with an image of Solomon and Sheba. He always liked the tapestry, because Sheba reminds him of someone he used to know:

Anselma, an Antwerp widow, whom he might have married, he often thinks, if he had not made up his mind suddenly to take himself back to England and pick up with his own people. In those days he did things suddenly: not without calculation, not without 
care, but once his mind was made up he was swift to move. And he is still the same man. As his opponents will find (Mantel, 2012, p. 436).

The observation that he is still the same man, that is, one who acts swiftly, provides a thin crust over the deeper and more disquieting question of whether he is still the same man in a moral respect. It is perhaps not nice to leave a lover as suddenly as we are made to think he once left Anselma, but certainly, no one would blame him for wanting to go home to England. The question is: can his present perfect swiftness be similarly condoned? ${ }^{4}$

In the midst of these reflections, someone of great importance to him comes in:

\begin{abstract}
'Gregory?' His son is still in his riding coat, dusty form the road. He hugs him. 'Let me look at you. Why are you here?' ... 'You ought not to ride about the country with just one attendant or two. There are people who would hurt you, because you are known to be my son' (Mantel, 2012, p. 436).
\end{abstract}

The moment of covert afterthought is thus enveloped by the memory of the love of his youth and his solicitude for Gregory, both providing evidence - for the reader as well as for himself - of his capacity to care deeply. Can this atone him morally? Does he need atonement?

Mantel is not the kind of writer who would seek to prove the goodness of a character. Thus, we cannot consult the novel for such proof. What we recognize as qualities of moral responsiveness in Cromwell are intricately woven into the fabric of his way of being, the directions of his attention, and the movement of his thought.

In a brief afterword to the later novel Mantel somewhat humorously observes that the historical Cromwell "remains sleek, plump and densely inaccessible, like a choice plum in a Christmas pie" (Mantel, 2012, p. 484). But the novels' Cromwell is not overly inaccessible; we find in him a highly intelligent person, playing a very dangerous game, deeply aware of the moral and practical hazards of his situation.

\title{
Moral luck, situationism and character
}

The Cromwell novels unsettle conventional morality by placing at the center of evil action a character whose moral instincts are so sound and who has so many undeniable virtues - a character not perfect, but quite different from the villain that Cromwell has often been portrayed as in history books. In this mode of unsettling conventions, the novels are far from unique, but they carry out a kind of distinctive moral work that is worth closer attention.

If there is a general moral lesson here, it would be that great evil can be done by the people we rightly recognize as good, because good character is only one part of what is needed for good action. Situations make snares for us, and we willingly contribute to their construction, without knowing what we are doing. Cromwell's superior capacities - talent, intelligence, loyalty and nerve - are the materials of his evil actions.

This could be articulated in terms of tragedy. Yet, Mantel's Cromwell is not a tragic hero, who just happens to do something with bad consequences or is forced by chance circumstances to do evil. He is, for example, not like Oedipus, who kills his father and marries his mother by mistake. He is something rather more complex, and rather guiltier, like one of us.

The moral life of the novels' Cromwell has two central characteristic features:

1. It develops as it does due to the nature of his central attachments to the world: his capacity to get things done, his crushing ambition, his commitment to work, his responsibility and love for his family, and his fidelity to two masters, the cardinal and the king.

\footnotetext{
${ }^{4}$ The theme of the tapestry, Solomon and Sheba, adds layers of potential complexity, which I will not got into here.
} 
2. Reliant on these attachments, given his surrounding society where human lives are cheap, he navigates morality as a matter of practical problem solving, where the central aims, for the most part, are not chosen by himself. Cromwell's pragmatic take on things is contrasted with the principled steadfastness of Thomas More, who is eventually executed for his refusal to accept the king's reforms. But the other side of More's steadfastness, in Mantel's story, is religious fanaticism and cruelty.

From the point of view of conventional ideas of moral agency, action, and what it means to be virtuous or guided by moral values, Cromwell's path may look like a degenerate form of practical morality. But the question that we may ask, with the novel, is whether our actual moral lives are not much more like Cromwell's than moral philosophers sometimes like to think: that good people do bad things and quite bad people do good things too, indeed do so actively, even willingly, in the course of realizing some of the potentials of their situation?

If we say yes to this, we might easily end up repeating a creed from the theoretical context of moral situationism: that good and bad action is wholly a matter of circumstances, that the idea of a consistent character is a kind of fiction and virtue ethics thus a meaningless pursuit.

This is the view of Gilbert Harman (1999), among others, who has claimed that social psychological research on human action reveals a "fundamental attribution error" concerning character. ${ }^{5}$ This is how he explains it: Casually we think of people as more or less generous, fair, honest, etc. But the evidence from some empirical studies indicates that people's actions are strongly situation bound, and there are no such stable character traits that would give a reliable outcome in cases where a given virtue is called for. It has been shown that people are generally more eager to help others when they have just found a coin in a vending machine, or that they are more likely to ignore people in need when they think they are in a hurry. The fundamental attribution error is, in this view, that we attribute stable character traits to people, where, in fact, there are only different situations that cause people to act differently.

From the situationist point of view, the discrepancy between Cromwell's actions and our assessment of him would mimic very well a discrepancy in our assessments of real people. It should, from this point of view, come as no surprise that Cromwell does evil things, in spite of our readiness to consider him a good man. In fact, something of this kind is expressed by Cromwell himself in the novel when he notes that "It is better not to try people, not to force them to desperation" (Mantel, 2012, p. 34).

Another theoretical framework that offers itself when thinking about Cromwell is the discussion of "moral luck", famously introduced to analytic moral philosophy by Bernard Williams (1981) and Thomas Nagel (1979). In the title essay of his book Moral luck, Williams takes issue with the assumption, familiar from both ancient and modern philosophy, that the goodness of the good person is immune to the vicissitudes of circumstance. With the aid of a few fictive examples, he seeks to show that circumstances beyond a person's control can indeed be decisive for our proper judgment of his actions as good or bad. Attention to luck works as a kind of reminder concerning the role of circumstances in moral life, but it does not as such undermine the idea that people may have a good or bad character. Thus, while reflections on moral luck contribute to discourse on virtues and character, the situationist perspective, as rendered by Harman, is something of a conversation stopper.

What I want to do here is to retain the reminder provided by the idea of moral luck, complicate it by some insights derived from the situationist perspective, and yet avoid the latter's negative conclusion concerning the role of virtues and character.

Rather than defining virtues as "stable, general dispositions to action", and moral character as the possession of such dispositions, we may approach the matter in a more open-ended manner. What is it that we talk about when we talk about goodness, good character and virtues,

\footnotetext{
${ }^{5}$ For a related discussion, see John Doris (2002).
} 
in the face of our (practical and empirical) knowledge of the fickleness of moral performance in demanding situations?

Neither the character Cromwell, nor Mantel the author, suggests that there would be no such thing as character. People are very different from each other and react to difficult situations in more various ways than simple moral psychological experiments can capture. While knowing that it is generally better not to try people, the fictive Cromwell navigates his social relationships very much in terms of character, assessing very carefully whom to trust and why, and what people's moral and personal strengths and weaknesses are. We are in no doubt about the fact that such navigation is an essential part of human relations, politics, and diplomacy, and that those capable of reading others in these respects have a great social asset.

The author on her part not only presents us with the complex judgments of this character, but also gives us the character himself as a paradox. We judge him to be good even while he schemes, spies, persecutes and kills. And when seeing this paradoxical unity as a possibility, we learn something about morality that ethically more straightforward narratives (like those of Eichmann and Michael Corleone) would not help us to understand.

\section{A reorientation in moral philosophy?}

I suggested earlier that Cromwell claims not just our sympathies but also our moral sympathies, because his dangerous characteristics are so closely linked to features that we admire: love, loyalty, ambition. But I also suggested that this is a very preliminary answer. I will attempt a complementary answer now, which can help us toward a reorientation in moral philosophy.

A great part of our sympathy with Cromwell has to do with the fact that we are not invited to judge him, but rather to judge with him. We see what he sees, and follow his judgments, which are consistently intelligent, observant, vigilant. We do not get so much of his "inner life", his "psychology", his hopes and dreams: he is very much a man of action and activity. What we do get, frequently enough, is his reasoning, what he sees, and how he navigates the various pressures of his surroundings. The two novels remain loyal to Cromwell: we do not find him corrupted, we continue to find his judgments sound, given the circumstances. But with him we are forced to navigate the encumbrances of character, strivings, other people and situations. "Better not to try people", is in the end not merely a reflection on society, but a plea on his own behalf.

From the perspective of moral philosophy, the novel can be read as a long meditation on the interplay of character and circumstance. What people are like matters a lot, but people are never just a set of moral attributes: they are complex and inconsistent. What society is like matters even more; societies are complex as well and offer us inconsistent guidance on how to live. However, concerning any society, we may ask a number of questions: What does it put people through? Does it have a role for the killer, for the spy, for the unquestioning servant of power? Does it make us fight for opportunities, jobs, the necessities of life? Does it teach us that violence is normal and necessary? What does it teach us about being a man or a woman, a master or a servant, a nobody or a somebody? What kinds of choices does it give people? What does it mean to have power in a given society, and how is power operated?

The Cromwell novels transpose the focus of moral thought, from general principles, theories, universal precepts, moral lessons, or virtues, to the complex intense confrontation of a character with a world. We see Cromwell making his world, but also the world making Cromwell. What this brings to the fore is the contingent world that is his. It is a fictional world, and a reconstructed, staged historical world, and yet in many quite deliberate ways a reflection of our world. Its problems and conflicts and limitations are different than those of our world, but perhaps precisely by virtue of these differences it works as a means for thinking about our own situation, our conditions, allegiances, necessities. 
Thus, perhaps paradoxically the "unreal" world of fiction brings us closer to looking at contingent realities, settings, times, and places, in moral philosophy. It teaches us the necessity of a world in moral thought. Whether we want to articulate a moral theory, or propose a normative framework, or postulate an ideal, or define our central moral concepts in helpful ways, we better know who or what we are and what our world is like, what people encounter out there, and how their moral precepts or characters do or do not serve them.

One thing that narrative literature can do, generally, is to bring the world, or worlds, into moral philosophy. What is distinctive to the Cromwell novels (though not only to them) is that the dialectics and tension between character and world is foregrounded, and the philosophical reader is invited to remain in that tension. From the stories of Eichmann and Corleone we walk out with a familiar morale directed at the moral failures of people or groups of people. But these familiar morals can also divert us from looking at the circumstances that make or break people. Mantel's Cromwell, at least up to the end of Bring up the bodies, is precisely designed to subvert the formulation of a general morale, to the benefit of a keener perception of circumstances. Remaining in the tension between character and world may be frustrating for those who like neat theoretical and normative solutions. Yet the practical benefit of this perspective is that it may help us to build a real world where good people are not unnecessarily compromised by circumstances.

\section{Acknowledgement}

Earlier drafts of this paper have been presented at the conference Frontiers in the Philosophy of Literature, University of Southern Denmark, Odense, 2015, at the Philosophical Society, Uppsala University, 2016, and at the conference In/outside the Frame, University of Pardubice, 2018. I want to thank Niklas Forsberg for valuable comments along the way. This publication was supported within the project of Operational Programme Research, Development and Education (OP VVV/OP RDE), "Centre for Ethics as Study in Human Value", registration No. CZ.02.1.01/0.0/0.0/15_003/0000425, co-financed by the European Regional Development Fund and the state budget of the Czech Republic.

\section{References}

ARENDT, H. (2006): Eichmann in Jerusalem: A report on the banality of evil. New York: Penguin.

CRARY, A. (2016): Inside ethics: On the demands of moral thought. Cambridge, MA: Harvard University Press.

DIAMOND, C. (1991): The realistic spirit. Cambridge, MA: The MIT Press.

DORIS, J. (2002): Lack of Character: Personality and Moral Behavior. Cambridge: Cambridge University Press.

HARMAN, G. (1999): Moral Philosophy Meets Social Psychology: Virtue Ethics and the Fundamental Attribution Error. In: Proceedings of the Aristotelian Society, 99(1), pp. 315-331. FELSKI, R. (2008): Uses of literature. Oxford: Blackwell.

FELSKI, R. (2015): The limits of critique. Chicago, IL: Chicago University Press.

KIERAN, M. (2003): Forbidden knowledge: The challenge of immoralism. In: J. L. Bermúdez \& S. Gardner (eds.): Art and morality. London: Routledge, pp. 56-73.

MANTEL, H. (2009): Wolf Hall. London: HarperCollins.

MANTEL, H. (2012): Bring up the bodies. London: HarperCollins.

MOI, T. (2017): Revolution of the ordinary: Literary studies after Wittgenstein, Austin, and Cavell. Chicago, IL: Chicago University Press.

MURDOCH, I. (1992): Metaphysics as a guide to morals. London: Chatto \& Windus. 
MURDOCH, I. (1997): Existentialists and mystics: Writings in philosophy and literature. London: Chatto \& Windus.

NAGEL, T. (1979): Mortal questions. New York: Cambridge University Press.

NUSSBAUM, M. (1986): The fragility of goodness. Cambridge: Cambridge University Press.

NUSSBAUM, M. (1990): Love's knowledge: Essays on philosophy and literature. Oxford:

Oxford University Press.

PACOVSKÁ, K. (2019): Moral character and the significance of action: Judging Dmitri Karamazov. In: Philosophical Investigations, 42(4), pp. 333-394.

RORTY, R. (1989): Contingency, irony, and solidarity. Cambridge: Cambridge University Press.

TAYLOR, C. (1989): Sources of the self: The making of modern identity. Cambridge: Cambridge University Press.

VOGLER, C. (2007): The moral of the story. In: Critical Inquiry, 34(1), pp. 5-35.

WILLIAMS, B. (1981): Moral luck. Cambridge: Cambridge University Press. 